in addition, a report of a discussion upon chemical and alchemical symbolism; a translation of "The Visions of Zosimos", by Dr. Taylor ; and reviews of four recent books, including notably Prof. Partington's "Origins and Development of Applied Chemistry" and Prof. J. Read's "Prelude to Chemistry". The nature of these two works, differing so widely in scope and treatment, conveys some idea of the ambit of Ambix.

\section{Public Health in British India during 1934}

The annual report of the Public Health Com. missioner with the Government of India (vol. 1), recently issued, surveys the vital statistics, public health and public health services of British India for the year 1934 (Government of India Press, New Delhi, 1936. Rs. 6 As. 2, or 10s.). The mid-year population is estimated to be, $275,753,570$, the births were $9,288,897$, a rate per 1,000 of 34 , and the deaths numbered $6,856,244$, a rate per 1,000 of 25 . The infant mortality per 1,000 live births was 187. Of the causes of death, malaria heads the list with $1,319,026$ deaths, and this figure does not include the mortality caused indirectly by malaria. Deaths from respiratory diseases numbered 483,018, those from dysentery and diarrhœa 285,110 and from cholera 199,708. Smallpox, with 83,928 deaths, caused a greater mortality than plague, with 80,131 deaths. At the Research Institute, Kasauli, a number of cases of snake-bite have been treated with antivenomous serum with a high percentage of recoveries -25 out of 29 cases of cobra bite, and 12 out of 13 cases of bite by Russell's viper. Lieut.-Colonel Jolly, the Commissioner, believes that the intensive public health propaganda carried out during the last ten or twelve years is beginning to bear fruit, and that interest is increasing in such matters as rural reconstruction, nutrition, child welfare and the prevention of epidemics.

\section{Examinations in the United States}

Examination, as a teacher's tool, has undergone remarkable modification in the past sixteen years in the United States. The search for an instrument of precision for the use of teachers in examining their pupils has engaged the ingenuity of a host of investigators, and the resultant devices, the true-false, the completion, the matching, the multiple-choice, the one-word, the problem and other objective-type tests have, to a large extent, supplanted the essay test. The United States Office of Education has recently issued a report (Bulletin 9/1936, Washington : Supt. of Documents. 10 cents) on testing practices of secondary school teachers of 1,600 schools, as described by themselves. It appears that, when constructing tests, about seventy-four per cent of them make use principally of the objective type, only sixteen per cent rely chiefly on the essay test and ten per cent make equal use of both. The report shows that the new style of tests is popular with teachers. Their simplicity appeals to them. But it is clear that their employment calls for watchful control. A principal advantage claimed for them-that a large number of items can be answered in a short time and the subject-matter can thus be the more thoroughly sampled-has been unrealized in many cases through not using a sufficient number of questions. Of intelligence tests, the report says that few teachers really use the results.

\section{The Swiss Earthquake Service}

THE Swiss Seismological Commission, afterwards the Swiss Earthquake Service, is the oldest committee engaged in the study of earthquakes. For its foundation in 1878, we are indebted to the veteran geologist, Prof. Albert Heim. Two years later, it was followed by the British Association Committee on earthquakes in Japan, which, on Prof. Milne's return to Great Britain in 1895, enlarged its scope as the Seismological Committee. In 1883, shortly after the destructive Ischian earthquake of July 28, a geodynamic section was added to the Central Meteorological Office at Rome, which still carries on its useful work of studying Italian and other earthquakes; and, in 1892, the Imperial Earthquake Investigation Committee began its similar, but more extensive, work in Japan. The Swiss Committee, under the direction of Dr. E. Wanner, has recently issued its Jahresbericht for 1935, containing three valuable tables, the first on earthquakes sensible in Switzerland, twenty-seven in number, none of which reached destructive intensity ; the second, of eighty earthquakes with origins as a rule less than three hundred miles distant; and the third, of a hundred and fifty earthquakes recorded at the five Swiss stations (Zurich, Chur, Neuchâtel, Basel and Sion), the distances of the origins being not less than six hundred miles.

\section{Discussion on Lubrication and Lubricants}

THE Council of the Institution of Mechanical Engineers, with the co-operation of other societies and institutions, has decided to hold a general dis. cussion on lubrication and lubricants on October 13 15, when a series of some 140 papers from leading authorities throughout the world will be presented. The opportunity will be taken to review the present state of knowledge by means of a general discussion among those especially interested and qualified to discuss the major problems of the subject, with objects such as to endeavour to establish a correlation between theory and practice and to show how bearing design can be applied, to relate academic research with trade practice, to obtain current views upon bearing metals, and to review the significance of laboratory tests, including wear and friction tests. An exhibition will be held at the Science Museum, South Kensington, to illustrate the subjects under discussion, and will be devoted to lubricants, bearings and bearing materials, as well as to testing and other apparatus. The exhibition will be open for a fortnight from October 13. Support for the discussion has been given by twenty-nine British societies and technical institutions and by ten over-seas societies and technical bodies. The complete proceedings will be issued as a bound volume. Advance copies of the papers will be available for use at the meetings. 